Journal : JMMR (Jurnal Medicoeticolegal dan Manajemen Rumah Sakit), 9 (2): 146-153, August 2020

Website : http://journal.umy.ac.id/index.php/mrs

DOI : $\quad$ https://doi.org/10.18196/jmmr.92125

\title{
Spirituality in The Workplace: Solution to Reduce Nurse Turnover intention
}

Nikma Fitriasari

Correspondence Author : nikmafitriasari@ub.ac.id

Master of Hospital Management Medical Faculty Univeristas Brawijaya, Indonesia

I N D E X I N G

Keywords:

Spirituality in the

Workplace;

Turnover

Intention;

Nurse;

\begin{abstract}
A B S T R AC T
A frequent problem in hospitals is nurse turnover, which reaches $27.3 \%$ annually in Indonesia. The solution to this problem is increasing spirituality intelligence through the formation of spirituality in the workplace. Good spirituality in the workplace can increase productivity and organizational commitment, and reduce turnover. The study was conducted to determine the effect of spirituality in the workplace on nurse turnover intention. The study used a quantitative design with a cross-sectional approach. The sample used was 92 nurses who were determined by Proportionate Random Sampling. Data was processed using Partial Least Square (PLS). The PLS results showed $\mathrm{T}$ statistics of 8.927 with direct coefficients of -0.423 . The application of spirituality in the workplace shapes nurses' perceptions more positively towards hospitals, so that, nurse turnover intention is low.
\end{abstract}

Kata kunci:

Spiritualitas di Tempat Kerja; Intensi Turnover; Perawat;

Masalah di rumah sakit yang sering terjadi adalah turnover perawat, yang mencapai $27.3 \%$ setiap tahun di Indonesia. Solusi untuk masalah ini adalah meningkatkan kecerdasan spiritualitas melalui pembentukan spiritualitas di tempat kerja. Spiritualitas di tempat kerja yang baik dapat meningkatkan produktivitas dan komitmen organisasi, dan mengurangi turnover. Penelitian dilakukan untuk mengetahui pengaruh spiritualitas di tempat kerja pada intensi turnover perawat. Penelitian menggunakan desain kuantitatif dengan pendekatan cross sectional. Sampel yang digunakan adalah 92 perawat yang ditentukan secara Proportionate Random Sampling. Data diolah menggunakan Partial Least Square (PLS). Hasil PLS menunjukkan statistik T 8.927 dengan koefisien langsung -0.423. Penerapan spiritualitas di tempat kerja membentuk persepsi perawat lebih positif terhadap rumah sakit sehingga intensi turnover perawat rendah.

(C) 2020 JMMR. All rights reserved

Article History: Received 2020-06-18; Revised 2020-07-15; Accepted 2020-08-13

\section{INTRODUCTION}

Human resource is an important asset in the hospital. Hospital performance is determined by the condition and behavior of human resource. The human resource problem that often occurs is nurse turnover, which reaches $27.3 \%$ annually in Indonesia (Budiono \& Alamsyah, 2015). Nurse turnover causes losses for the hospital, especially if he has skills, and it increases a recruitment cost (Sabilla \& Sri Padmantyo, 2017).

Turnover is an embodiment of behavioral patterns from nurses' psychological reactions. Psychological reaction, in the form of dissatisfaction, thoughts of leaving work, intending to look for other work alternatives, and intention to make the turnover itself (Demirtas \& Akdogan, 2015). One effort to form a psychological nurse is fulfilling the needs of spirituality in the workplace. Spirituality in the workplace can create a conducive work 
atmosphere for nurses (Nurtjahjani, 2010).

Spirituality in the workplace is not about religion. It is a framework of organizational cultural values that encourages nurses' transcendent experiences through work processes, facilitates feelings of connection with others, and provides complete and happy feelings (Nurtjahjani, 2010). Spirituality in the workplace is able to direct nurses in dealing with problems at work, especially when they experience demotivation, under pressure and disciplinary action. Spirituality in the workplace reduces absenteeism, reduces turnover intentions, and increases work productivity (Budiono \& Alamsyah, 2015).

Spirituality in the workplace has three indicators, namely inner life, meaningful work, belonging to the community (Ashmos \& Duchon, 2000). Inner life means that employees have a meaningful inner life as a strength in born life. The organization understands that employees have an inner life. Meaningful work means that employees have a need to find meaning and purpose in life at work. The organization provides facilities to fulfill inner needs, not just born needing. Belonging to the community means that employees have relationships with colleagues and become part of the organization (Lips-Wiersma \& Mills, 2014).

Spirituality in the workplace is a counterweight to personal and professional life through efforts to integrate the value of personal life with work conditions and an in-depth search of life by interpreting work. Hospitals that implement spirituality in the workplace see that every employee has spiritual needs, has a desire to find meaning and purpose in life at work, and has a desire to be part of the hospital (Siswanto, 2012).

The study of spirituality in the workplace becomes an interesting thing to study and apply, because it is able to significantly influence individuals in organization changing (Budiono \& Alamsyah, 2015). Spirituality in the workplace according to (ICSW) The International Center for Spirit at Work is about individual and organization who see work spiritually, as an opportunity to grow and contribute to society as a form of caring, compassion, and honest attitude towards oneself and other people (Harris et al., 2019). Spirituality in the workplace does not bring religion into work, but the ability to present the whole person to work. The nurse works more effectively because he sees work as a means to improve spirituality, not a means to get money. Spirituality in the workplace can increase the competitiveness of hospitals in the era of globalization (Nurtjahjani, 2010).

The application of spirituality in the workplace can reduce the turnover intention of non-nurse employees at Al-Irsyad Hospital in Surabaya (Kistyanto, 2013). The application of spirituality in the workplace can also reduce the intention of nurse turnover at Unisma Islamic Hospital Malang (Budiono \& Alamsyah, 2015). The application of spirituality in the workplace will form employees having a positive perception of the organization, better adjustments, strong commitments and achieving higher satisfaction. The greater the employee spirituality, the lower the turnover intention (Rego \& Pina e Cunha, 2008).

Turnover intention is the desire felt by employees to leave the organization. Turnover intention always precedes turnover (Srinadi \& Supartha, 2015). Turnover intention analysis give benefits the organization more than analyzing actual turnover. There are three indicators to measure employee turnover intention, namely the intention of leaving the organization, the intention of finding a new job, and the intention to find a new job several times. Early detection of employee turnover intentions can reduce actual turnover rates (Wang et al., 
2016). Organizational efforts when getting the results of high employee turnover intentions are to improve emotional intelligence, increase spirituality intelligence, minimize work stress, increase job satisfaction, and increase organizational commitment (Utomo, 2016).

RSI is a private hospital in Malang. RSI is one of the hospitals that applies the concept of spirituality in the workplace. This can be seen in the hospital's architecture which features Islamic symbols and Islamic atmosphere with the hearing of religious songs reaching the inpatient room. RSI also conducts routine religious activities such as congregational prayer, reciting the Alquran, and studying Islamic sciences. RSI has a low nurse turnover rate of $6,41 \%$. The low turnover rate has become a major investment for RSI to achieve effective and efficient services. This indicates the existence of factors supporting the low turnover rate of nurses, one of which is allegedly due to the application of spirituality in the workplace. This study aims to determine the effect of spirituality in the workplace on RSI nurse turnover intention.

\section{RESEARCH METHOD}

The study used a quantitative research design with a cross-sectional approach. It used two variables, namely spirituality in the workplace as an independent variable and turnover intention as a dependent variable. The study was conducted at the RSI Malang in August 2018. The population was all RSI nurses. The sampling used Proportionate Random Sampling in the Emergency Installation, Outpatient Unit, Inpatient Unit, and Management. With Slovin's calculation, 92 nurses were obtained as respondents. Data is collected by distributing questionnaire sheets to respondents. Data were analyzed with descriptive analysis and Partial Least Square (PLS). The statistic hypothesis is that spirituality in the workplace decreases turnover intention.

\section{RESULT AND DISCUSSION}

Most respondents were female by $78.3 \%$, aged $26-35$ years by $50.0 \%$, educated D3 by $76.1 \%$, marital status by $82.6 \%$, and had worked for less than or equal to 10 years by $67.4 \%$ (Table.1). Most of the nurses were women because those interested in the nursing profession are still dominated by women (Retnaningsih \& Fatmawati, 2018). Most nurses age 26-35 years who are included in young adulthood. Young adulthood is a productive age that has relative advantages in physical terms, namely speed, agility and good coordination (Aprilianti, 2017). Most nurses have D3 education because hospitals need D3 nurses to do nursing care (Fauzi, 2018).

Most nurses are married because employees with marital status have responsibilities to the family, so getting a permanent job is important and valuable (Wati, 2016). Most nurses work for less than or equal to 10 years along with the number of nurses who are mostly young adulthood. Nurses who work for less than or equal to 10 years have good knowledge because they have accurate information to make decisions in the nursing care process through online scientific articles (Hengky, 2017). 
Table.1 Respondent Characteristics

\begin{tabular}{|c|c|c|}
\hline Characteristic & Frequency & Percentage \\
\hline \multicolumn{3}{|l|}{ Gender } \\
\hline Male & 20 & $21.7 \%$ \\
\hline Female & 72 & $78.3 \%$ \\
\hline \multicolumn{3}{|l|}{ Age } \\
\hline$\leq 25$ tahun & 16 & $17.4 \%$ \\
\hline $26-35$ tahun & 46 & $50.0 \%$ \\
\hline $36-45$ tahun & 26 & $28.3 \%$ \\
\hline 45 tahun & 4 & $4.3 \%$ \\
\hline \multicolumn{3}{|l|}{ Education } \\
\hline S1 & 22 & $23.9 \%$ \\
\hline D3 & 70 & $76.1 \%$ \\
\hline \multicolumn{3}{|l|}{ Married status } \\
\hline Married & 76 & $82.6 \%$ \\
\hline Single & 15 & $16.3 \%$ \\
\hline Divorce & 1 & $1.1 \%$ \\
\hline \multicolumn{3}{|l|}{ Lenght of work } \\
\hline$\leq 10$ years & 62 & $67.4 \%$ \\
\hline 10.20 years & 23 & $25.0 \%$ \\
\hline$>20$ years & 7 & $7.6 \%$ \\
\hline
\end{tabular}

Source: The Result of Statistic Analysis

Descriptive analysis results can be seen in Table.2 Descriptive analysis results of the spiritual in the workplace variable found the average value was 4.08, meaning that nurses' spirituality in the workplace at the RSI was high. This is in accordance with the research which states that nurses at Malang UNISMA Islamic Hospital have a high spirituality in the workplace value as indicated by the recognition that they work as part of their self-service to God (Budiono \& Alamsyah, 2015). Self-service to God is one form of value from meaning work. Descriptive analysis resulting on turnover intention variables obtained an average value was 1.95; meaning that the intention of RSI nurse turnover was low. The low turnover intentions are influenced by organizational commitment, where organizational commitment has three indicators, namely the feeling of being part of the organization, the interest or enthusiasm for work, and the existence of confidence in management (Alhempi, 2015). RSI's commitment in shaping spirituality in the workplace is one of the determinants of nurses' low turnover intentions.

Table.2 Descriptive Analysis Results

\begin{tabular}{|l|c|}
\hline \multicolumn{1}{|c|}{ Indicator } & Average \\
\hline Inner life (X1.1) & 4.11 \\
\hline Meaning work (X1.2) & 4.16 \\
\hline Belonging to the community (X1.3) & 3.98 \\
\hline Spirituality in the workplace (X) & 4.08 \\
\hline Intention to out from the workplace (Y1) & 1.99 \\
\hline Intention to find a new job (Y2) & 1.98 \\
\hline Intention to find jobs several times (Y3) & 1.88 \\
\hline Turnover Intention (Y) & 1.95 \\
\hline
\end{tabular}

Source: The Result of Statistic Analysis 
The results of statistical analysis can be seen in Figure 1.

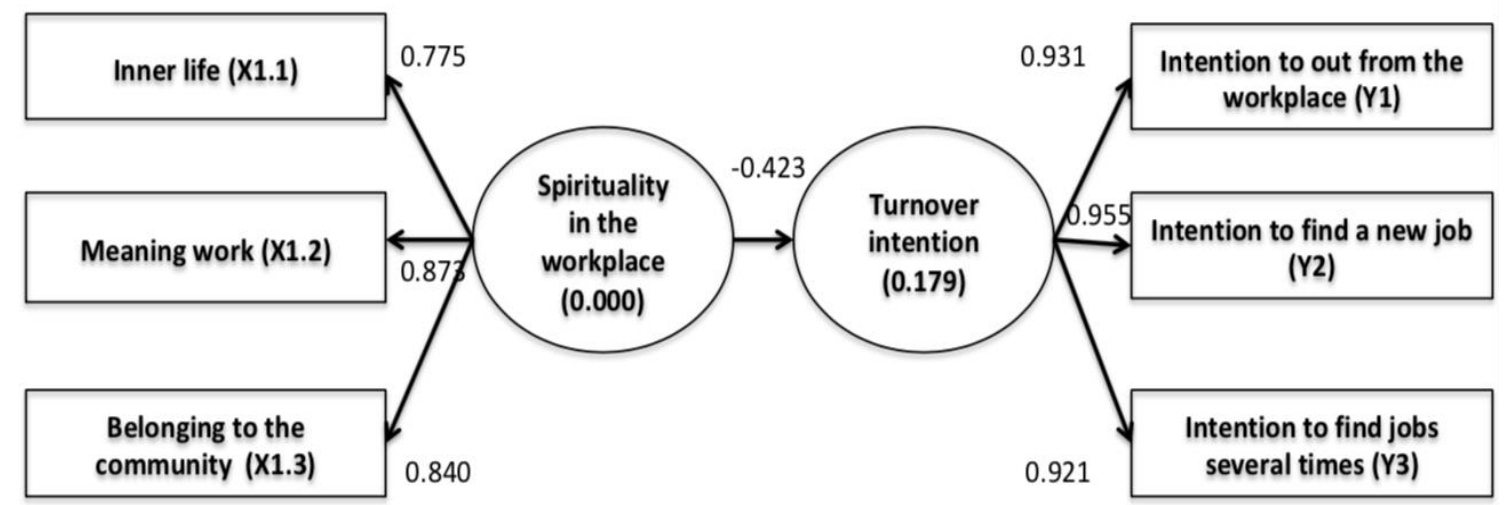

Figure. 1 the Result of PLS Analysis

Source: The Result of Statistic Analysis

The results of the measurement model of the PLS obtained the greatest loading factor value in spirituality in the workplace was the meaning of the work indicator (X1.2) of 0.873 and at turnover intention was the desire to find a new job (Y2) of 0.955. This shows that the meaning work indicator (X1.2) was the most dominant indicator in measuring spirituality in the workplace variable, and the indicator for the intention to find a new job (Y2) was the most dominant indicator in measuring turnover intention variable.

The results of the structural model obtained the Goodness of a fit model value of 0.179. This showed that the contribution of spirituality at the workplace was $17.9 \%$ in shaping the turnover intention of RSI nurses. Hypothesis test results obtained a statistical T value of 8.927 with direct coefficients of -0.4423 . That was, spirituality in the workplace had a significant effect on the turnover intention of RSI nurse.

The meaning work indicator (X1.2) was the most dominant indicator in measuring spirituality in the workplace variable. Meaningful work relates to the extent to which an individual in his work seeks to find something more important in order to find the meaning or purpose of his life, live his dreams, express the deep necessities of life through the search for the importance of a job, and in order to contribute and benefit to others (Harris et al., 2019). This is consistent with exploratory research which states that there are 2 (two) factors that shape spirituality in the workplace. The first factor is a sense of purpose and meaning in work that is driven by the mission and values of the organization. The second factor is feeling comfortable, free, and experiencing personal development which is supported by the concern of the organization to bring the interests of the organization together with individual interests (Rego \& Pina e Cunha, 2008).

The indicator intention to find a new job (Y2) was the most dominant indicator in measuring the turnover intention. This is in accordance with the turnover model proposed that turnover begins with a decrease in satisfaction, thinking out, intending to find a new job, comparing new and old jobs, and finally deciding to leave. Turnover intention was first formed with an intention to find a new job (Ridlo, 2012). The condition of the intention turnover at the RSI illustrated that nurses have low intention to find new jobs.

Goodness of a fit results show that the contribution of spirituality in the workplace 
informing turnover intentions is $17.9 \%$, while the remaining $81.2 \%$ is the contribution of other factors not discussed in this study. Factors forming turnover intentions can be grouped into three groups, namely external factors (the availability of other work alternatives), organizational factors (salary, rewards, supervision, work environment, supervisor style, organizational culture), and individual factors. Individual factors are divided into individual factors related to work and individual factors not related to work. Individual factors related to work in the form of job autonomy, unattractive work, challenging work, and job dissatisfaction. Individual factors not related to work are age, length of work, and education level (Alfa et al., 2016).

The results of the study proved that spirituality in the workplace had a negative effect on nurse turnover intentions significantly so that the hypothesis in this study was accepted. The greater the individual spirituality, the lower the turnover intention (Milliman et al., 2003). The results of Rego and Pina e Cunha's research also state that the application of spirituality at the workplace will stimulate employees to form more positive perceptions of the organization. This positive perception can form employee loyalty so that the desire to leave the organization is low (Rego \& Pina e Cunha, 2008). Research, Wang et al. states that employee turnover intentions are influenced by spiritual management, in the form of organizational commitment, work stress, job characteristics, promotions, salary and compensation, and quality of work life (Wang et al., 2016).

A hospital that implements spirituality in the workplace will form employees, including nurses, to feel a meaningful part of the hospital. He will try to work better, not be absent from work, and form a more conducive work environment. Furthermore, he can better control their work and increase the meaning of their work (Kistyanto, 2013).

Spirituality is very effective in directing human behavior in dealing with life problems, especially in the workplace, especially when employees experience demotivation, under pressure or even disciplinary action. This is because high spirituality will guide human beings to always think positively and try to achieve a better quality of life, which can stimulate the moral imagination of employees to be able to deal with ethical issues in the organization (Rahayuningsih, 2012).

\section{CONCLUSION}

The results of the study concluded that spirituality in the workplace influences turnover intentions. The higher the spirituality in the workplace, the lower the nurse turnover intention at the RSI. Advice that can be given to hospitals is to strengthen spirituality in the workplace with an organizational approach. This is consistent with the results of research that shows that belong to the community have the lowest value. An organizational approach to strengthening spirituality in the workplace can be done by introducing the vision and mission of the hospital that contains the values of spirituality on an ongoing basis in every hospital activity, giving responsibility and autonomy to employees in decision-making, giving rewards to employees by developing talent and his skills, and facilitating employee responsibilities towards his family and social obligations. 


\section{REFERENCE}

Alfa, M. Z., Murni, S., \& Roring, F. (2016). Faktor-Faktor yang Mempengaruhi Pemutusan Hubungan Kerja Karyawan pada PT. PLN (Persero) Rayon Manado Utara. Jurnal EMBA: Jurnal Riset Ekonomi, Manajemen, Bisnis Dan Akuntansi, 4(1).

Alhempi, R. R. (2015). Pengaruh Komitmen Organisasi Dan Ketidakamanan Pekerjaan (Job Insecurity) Terhadap Intensi Turnover Tenaga Pengajar Di Sekolah Abc Pekanbaru. Jurnal Ekonomi KIAT, 25(2), 1-28.

Aprilianti, C. (2017). Otonomi Perempuan Terhadap Tenaga Penolong Persalinan Di Kota Palangka Raya. Jurnal Kebidanan Indonesia: Journal of Indonesia Midwifery, 8(2).

Ashmos, D. P., \& Duchon, D. (2000). Spirituality at work: A conceptualization and measure. Journal of Management Inquiry, 9(2), 134-145.

Budiono, S., \& Alamsyah, A. (2015). Pengaruh Spiritualitas di Tempat Kerja terhadap Turnover Intention Perawat melalui Komitmen Organisasional di Rumah Sakit Islam Unisma Malang. Jurnal Aplikasi Manajemen-Journal of Applied Management, 12(4), 639649.

Demirtas, O., \& Akdogan, A. A. (2015). The effect of ethical leadership behavior on ethical climate, turnover intention, and affective commitment. Journal of Business Ethics, 130(1), 59-67.

Fauzi, M. F. Bin. (2018). Hubungan Tindakan Tenaga Perawat dengan Pengetahuan dan Sikap Terhadap Aspek Kesehatan dan Keselamatan Kerja di Rumah Sakit USU Tahun 2018.

Harris, D. E., Holyfield, L., Jones, L., Ellis, R., \& Neal, J. (2019). Spiritually and Developmentally Mature Leadership: Towards an Expanded Understanding of Leadership in the 21st Century. Springer.

Hengky, M. (2017). Hubungan Persepsi Perawat Terhadap Gaya Kepemimpinan Kepala Ruang Dengan Kinerja Perawat Pelaksana Di Rs Pku Muhammadiyah Bantul. STIKES Jenderal Achmad Yani Yogyakarta.

Kistyanto, A. (2013). Pengaruh Spiritualitas di tempat kerja terhadap Turnover Intention melalui Komitmen Organisasi. IQTISHODUNA.

Lips-Wiersma, M., \& Mills, A. J. (2014). Understanding the basic assumptions about human nature in workplace spirituality: Beyond the critical versus positive divide. Journal of Management Inquiry, 23(2), 148-161.

Milliman, J., Czaplewski, A. J., \& Ferguson, J. (2003). Workplace spirituality and employee work attitudes: An exploratory empirical assessment. Journal of Organizational Change Management, 16(4), 426-447.

Nurtjahjani, H. (2010). Spiritualitas kerja sebagai ekspresi keinginan diri karyawan untuk mencari makna dan tujuan hidup dalam organisasi. Jurnal Psikologi, 7(1), 27-30.

Rahayuningsih, D. A. (2012). Spiritual Value: Apa Dan Bagaimana (Kajian Pada Perilaku Manusia, Lingkungan Kerja Dan Mekanisme Akuntansi). Jurnal Media Bisnis. September, Hal, 23.

Rego, A., \& Pina e Cunha, M. (2008). Workplace spirituality and organizational commitment: An empirical study. Journal of Organizational Change Management, 21(1), $53-75$. 
Retnaningsih, D., \& Fatmawati, D. F. (2018). Beban Kerja Perawat terhadap Implementasi Patient safety di Ruang Rawat Inap. Jurnal Keperawatan Soedirman, 11(1), 44-52.

Ridlo, I. A. (2012). Turnover Karyawan "Kajian Literatur." Surabaya: PH Movement Publication.

Sabilla, A. P., \& Sri Padmantyo, M. B. A. (2017). Pengaruh Stres Kerja Terhadap Turnover Intention Karyawan Dengan Dukungan Sosial Sebagai Variabel Moderating (Studi Empiris Pada PT. Driver Online Nusantara). Universitas Muhammadiyah Surakarta.

Siswanto, S. (2012). Workplace spirituality pada karyawan perbankan syariah. IQTISHODUNA.

Srinadi, N. N., \& Supartha, W. G. (2015). Peran Mediasi Kepuasan Kerja pada Hubungan Motivasi Kerja dengan Intention To Quit. EJurnal Ekonomi Dan Bisnis Universitas Udayana.

Utomo, H. J. N. (2016). Upaya Mencegah Terjadinya Intention To Leave Melalui Pendekatan Integratif.

Wang, J. H., Tsai, K. C., Lei, L. J. R., \& Lai, S. K. (2016). Relationships among job satisfaction, organizational commitment, and turnover intention: Evidence from the gambling industry in Macau. Business and Management Studies, 2(1), 104-110.

Wati, W. S. (2016). Implementasi sistem jenjang karir dalam pelaksanaan discharge planning. Jurnal Ilmu Keperawatan, 4(1), 34-43. 